\title{
Adherence of Glucan-Positive and Glucan-Negative Streptococcal Strains to Normal and Damaged Heart Valves
}

\author{
Carlos H. Ramirez-Ronda, Infectious Disease Section, Departments of Medicine \\ and Research, Veterans Administration Hospital and the University of \\ Puerto Rico School of Medicine, San Juan, Puerto Rico 00936
}

A B S T RA C T The adherence of 18 strains of streptococci to sections of normal canine and human aortic, mitral, and tricuspid valves and to canine interatrial septum was compared in an in vitro system. Quantitative measurements of adherence ratios were performed by two independent methods. Adherence ratios for Streptococcus mutans, S. sanguis, S. bovis, and Group D streptococci were higher (0.0058-0.0101) than for the other streptococcal strains studied (0.0025$0.0041)$. With the exception of Group D streptococci, adherence ratios for each bacterial strain were similar with the aortic, mitral, and tricuspid valve sections. Adherence ratios with normal human and canine valve leaflets were similar, but adherence ratios with interatrial septum were lower than with normal valve sections.

Adherence ratios for glucan-positive and glucannegative strains of streptococci with normal and with damaged aortic valve leaflets were also compared. The adherence ratios of the glucan-positive streptococci (S. mutans, S. sanguis, and S. bovis) and one glucannegative enterococcal strain (KG-3) were approximately five times higher with damaged aortic valves (0.039-0.051) than with normal aortic valves (0.0090.010 ). For glucan-positive strains, adherence ratios with normal aortic leaflets were similar when bacteria were grown in media which contains or lacks sucrose. In striking contrast, growth of the glucan-positive strains in medium which lacks sucrose, with resultant deficiency of glucan production, decreased the adherence ratios with damaged aortic valve leaflets to those found with normal aortic leaflets. Treatment of

This work was presented in part at the 16th Interscience Conference for Antimicrobial Agents and Chemotherapy, Chicago, Ill., 27-29 October 1976 and at the 17th Interscience Conference for Antimicrobial Agents and Chemotherapy, New York, 12-14 October 1977. Part of the work has been published in abstract form in 1976. Clin. Res. 24: 352A and in 1977. Clin. Res. 25: 382A.

Received for publication 26 September 1977 and in revised form 14 June 1978. glucan-positive strains with dextranase resulted in a decrease in their adherence ratios to levels seen with bacteria grown in medium lacking sucrose, but the higher adherence ratios could be restored in the presence of exogenous dextran.

It is concluded that glucan production is one quantitatively important factor that contributes to the greater adherence of glucan-positive streptococci to damaged rather than to normal aortic heart valve leaflets. However, glucan production is not the only factor that determines preferential adherence of streptococci to damaged heart valves, because glucan-negative strains may also show some degree of increased adherence to damaged valves. Thus, bacterial glucan production is one of the factors that could contribute to the pathogenesis of bacterial endocarditis.

\section{INTRODUCTION}

Gram-positive cocci adhere well to normal heart valves in vitro, whereas aerobic gram-negative bacilli do not adhere well with the exception of Pseudomonas aeruginosa (1). Colonization of a specific mucosal surface is an early event in the pathogenesis of many bacterial infections (2) and the ability of a given bacterial strain to adhere to a mucosal surface is one important factor in determining the localization of infections caused by the specific bacterial strain $(3,4)$. In addition, differences in adherence properties of bacterial pathogens may help to determine the most likely etiologic agent of infection at a particular anatomic site (5-9).

Streptococci are the most frequent organisms associated with endocarditis in man (10). Streptococcus sanguis the classic endocarditis, as well as $S$. bovis and $S$. mutans, are glucan-producing strains found in many patients with endocarditis (11-15).

The role of dextran in adherence of streptococci to teeth surfaces has been elegantly described by Gibbons and collaborators (16) in their studies on the 
cariogenic potential of $S$. mutans and its correlation with dextran production. Further clarification of the role of dextran came from the demonstration that adherence of $S$. mutans to smooth glass surfaces requires the synthesis of a water insoluble dextran-levan polymer and the participation of binding sites on the surfaces of the bacterial cell (17). Elliot suggested that dextran production may be of importance in the adherence of bacteria to heart valves (18). The role of dextran in adherence of streptococci to heart valves has not been systematically studied. To clarify the role of dextran in adherence to heart valves a series of experiments was designed. First, we wanted to expand our previous observation (1) and use a larger number of streptococcal strains including glucan-positive and glucan-negative strains. Second, we wanted to compare the adherence of every strain to the different valve leaflets. Third, to clarify the specificity or nonspecificity of adherence to valvular endothelia, we compared adherence to interatrial septa, a thin, nonvalvular endothelial tissue that could be handled like the valve leaflets in our in vitro system. Fourth, experiments were designed to study the adherence of streptococcal strains to heart valve leaflets covered with a nonbacterial thrombotic endocarditic lesion, platelets, and fibrin.
Finally, we studied the role of endogenous glucans and exogenous dextran in the adherence of glucan-positive and glucan-negative bacterial strains to normal and to damaged valves. Experiments were designed to study the role of endogenous glucans and of exogenous dextran in such adherence.

The data demonstrate that adherence of streptococcal strains to different heart valve leaflets is comparable. with the exception of Group D streptococcal strains which were found to adhere less well to tricuspid valve leaflets. Adherence to interatrial septa for the bacterial strains studied was lower than for any of the valve leaflets. Adherence to damaged valves was approximately five times higher than the adherence to normal valves. The adherence of glucan-positive strains to damaged valves was shown to be dependent on the presence of glucans.

\section{METHODS}

Bacterial strains and conditions of cultivation. The bacterial strains used in this study were obtained from various sources (Table I). All bacterial strains listed in Table I, that were isolated from clinical specimens for this study or our previous study (1), were lyophilized at the time they were originally isolated. All strains were used fresh after reconstitu-

TABLE I

Bacterial Strains and Sources Used in this Study

\begin{tabular}{|c|c|c|c|}
\hline Bacterial strain & Isolation & Provided by & Reference \\
\hline S. mutans 6715 & Laboratory strain & $\begin{array}{l}\text { R. J. Gibbons } \\
\text { Forsyth Dental Laboratory }\end{array}$ & $(4)$ \\
\hline S. salivarius $\mathrm{CM}-6$ & Laboratory strain & Forsyth Dental Laboratory & (9) \\
\hline S. mutans SS-909 & Laboratory strain & $\begin{array}{l}\text { R. Facklam (Center for } \\
\text { Disease Control) }\end{array}$ & - \\
\hline S. mutans SS-980 & Laboratory strain & R. Facklam & - \\
\hline S. mutans CR-1 & Blood (endocarditis) & Puerto Rico Medical Center & Present study \\
\hline S. faecalis 32426 & Blood (bacteremia) & $\begin{array}{l}\text { P. Southern } \\
\text { Parkland Memorial Hospital }\end{array}$ & Present study \\
\hline S. faecalis liquifaciens & Urine & Parkland Memorial Hospital & Present study \\
\hline S. faecalis zymogenes & Urine & Parkland Memorial Hospital & Present study \\
\hline S. durans & Urine & Parkland Memorial Hospital & Present study \\
\hline Enterococcus 26651 & Blood (bacteremia) & Parkland Memorial Hospital & Present study \\
\hline Enterococcus KG-3 & Blood (endocarditis) & Parkland Memorial Hospital & $(1)$ \\
\hline S. bovis CR-1 & Blood (endocarditis) & Puerto Rico Medical Center & Present study \\
\hline S. bovis CR-200 & Blood (endocarditis) & Puerto Rico Medical Center & Present study \\
\hline S. sanguis CR-100 & Blood (endocarditis) & Puerto Rico Medical Center & Present study \\
\hline S. sanguis CR-101 & Blood (endocarditis) & Puerto Rico Medical Center & Present study \\
\hline Group A streptococcus 25073 & Blood (bacteremia) & $\begin{array}{l}\text { P. Southern } \\
\text { Parkland Memorial Hospital }\end{array}$ & Present study \\
\hline Group B streptococcus 32114 & Blood (bacteremia) & Parkland Memorial Hospital & Present study \\
\hline Group C Streptococcus 33378 & Urine & Parkland Memorial Hospital & Present study \\
\hline Staphylococcus aureus G-4 & Blood (endocarditis) & Parkland Memorial Hospital & $(1)$ \\
\hline Staphylococcus epidermidis 6725 & Blood (bacteremia) & Parkland Memorial Hospital & (1) \\
\hline
\end{tabular}


tion. All strains were grown in trypticase soy broth (TSB) ${ }^{1}$ (BioQuest; BBL \& Falcon Products, Div. of Becton, Dickinson \& Co., Cockeysville, Md.) for adherence studies. Glucanpositive strains were grown in TSB supplemented with $5 \%$ sucrose when experiments comparing glucan-positive strains were needed. Experiments comparing adherence of a given strain in a medium which lacks sucrose were carried out with TSB. A control medium used which lacks sucrose was the chemically defined medium of Terleckyj et al. (19).

Preparation of standardized bacterial suspension. The standardized bacterial suspensions were prepared as previously described (1). Examination of the wet mounts of the bacterial suspensions by light microscopy demonstrated welldispersed bacterial cells without aggregates except for suspensions of $S$. mutans 6715 , which contained clusters with an average size of 3 to 4 bacteria per cluster. Viable counts of the standardized bacterial suspension $\left(A_{590}=0.3\right)$ were performed in every experiment, and for adherence studies the standardized suspensions were used undiluted and at serial 10-fold dilutions as noted for individual experiments.

Preparation of standardized sections of normal aortic, mitral and tricuspid valves and interatrial septa. In experiments utilizing normal canine valves, hearts were excised from dogs sacrificed for other purposes. In some cases the dogs were heparinized before sacrifice. The interatrial septum was chosen as a control, because it is a thin nonvalvular tissue with vascular endothelium on both sides and it can be cut with a skin punch biopsy in the same wax as valvular tissue. Human aortic, mitral, and tricuspid valves were also obtained from seven human cadavers at autopsy. The method for preparing standardized sections of canine and human heart valves with a 2-mm diameter skin biopsy punch under sterile conditions has been described previously (1). The same technique was used to prepare the interatrial septum sections.

Preparation of standardized sections of traumatized aortic valves with nonbacterial thrombotic endocarditis. Mongrel dogs of either sex weighing 14-16 kg were anesthetized by intravenous injection of pentobarbital $(50 \mathrm{mg} / \mathrm{kg})$. The neck region was shaved and an incision made to expose the left carotid artery. The vessel was ligated in its distal portion and a polyethylene-160 catheter (inside diameter 0.045 inches, outside diameter 0.062 inches; Clay-Adams, Div. of Becton, Dickinson \& Co., Parsippany, N. J.) containing sterile saline was introduced into the heart. The catheter was left in place for 18$20 \mathrm{~h}$. The aortic valve leaflets were removed by sterile techniques and placed in sterile phosphate-buffered saline (PBS). Sections were cut only from areas of the valves showing macroscopically visible damage. Microscopic examination of representative sections revealed deposition of fibrin and platelets on the traumatized endothelial surface.

Quantitative measurement of bacterial adherence to valve and interatrial sections. The bacteria were labeled with ${ }^{51} \mathrm{Cr}$ as previously described (1). The following standardized conditions were used for all experiments unless otherwise noted. Four valve sections were placed in $3-\mathrm{ml}$ samples of ${ }^{51} \mathrm{Cr}$ labeled suspensions of bacteria and were agitated at 16 cycles/ min on a reciprocating shaker at $25^{\circ} \mathrm{C}$ for $1 . \mathrm{h}$. Two pairs of valve sections were washed three times with $\mathrm{pH} 7.2 \mathrm{PBS}$ solution ( $\mathrm{NaCl}, 122.49 \mathrm{~g} ; \mathrm{Na}_{2} \mathrm{HPO}_{4}, 26.64 \mathrm{~g} ; \mathrm{KH}_{2} \mathrm{PO}_{4}, 7.75 \mathrm{~g}$; distilled water, 19 liters) and each pair was placed in a mortar with $3 \mathrm{ml}$ of PBS and $0.5 \mathrm{~g}$ of sterile sand and homogenized with a pestle until discrete pieces of tissue were no longer visible.

Quantitation of viable bacteria and ${ }^{51} \mathrm{Cr}$-labeled bacteria was performed with samples of the standardized bacterial sus-

${ }^{1}$ Abbreviations used in this paper: PBS, phosphate-buffered saline; TSB, trypticase soy broth. pensions, the homogenates of the valve sections, and the residual bacterial suspensions after removal of the heart valve sections as previously described (1). Counting was performed in a Beckman model 7000 gamma scintillation counter (Beckman Instruments, Inc., Fullerton, Calif.).

Adherence ratios were defined as the proportion of bacteria in the initial suspension that was recovered from the washed homogenized valve sections. The adherence ratios were calculated from measurement of radioactivity and from viable counts as described previously (1).

Statistical data was compared by using the $t$ test (20).

Adherence studies with dextranase-treated glucan-positive streptococci. Dextranase (Sigma Chemical Co., St. Louis, Mo., D-5884 crude powder, $28 \mathrm{U} / \mathrm{mg}$, solid lot $84 \mathrm{C}-0302$ ) was shown to be capable of depolymerizing dextran T-2000 (Pharmacia Fine Chemicals AB, Uppsala, Sweden, lot 8122) under conditions described by Murayama et al. (21). In some experiments dextranase was inactivated by prior heating at $60^{\circ} \mathrm{C}$ for $60 \mathrm{~min}$. Determination of dextranase activity after heat inactivation confirmed failure to depolymerize dextran T-2000.

Glucan-positive streptococcal strains were grown in TSB containing $5 \%$ sucrose for $18 \mathrm{~h}$. The bacterial cells were collected by centrifugation $(10,000 \mathrm{~g}$ for $15 \mathrm{~min})$, washed two times with PBS, and suspended to an OD of $0.3\left(A_{590}\right)$ in $10 \mathrm{ml}$ of PBS to which $0.2 \mathrm{mg} / \mathrm{ml}$ of dextranase was added. In some experiments the concentration of dextranase was varied as noted in the text. The cells were incubated for $1 \mathrm{~h}$ with the dextranase, centrifuged and washed three times with PBS, re-suspended in PBS, re-adjusted to $0.3 \mathrm{~A}_{590}$, and a colony count performed. Adherence studies were then carried out with the dextranase-treated cells by the methods described above with and without addition of exogenous dextran T-2000 at $5 \mathrm{mg} / \mathrm{ml}$.

Determination of glucan production, induction of glucannegative strains, and measurement of extracellular polysaccharide. Extracellular polysaccharide production (presumably glucan) was determined by an already published method (22).

Dextran production was also determined for all glucanpositive strains by the ethanol precipitation method of Hehre and Neill (15). Quantitative measurement of extracellular glucan production was also determined by the assay method of Hamada et al. (23).

Glucan production was determined before and after each experiment in which a dextran-positive strain was used. Determination of polysaccharide production by the glucan-positive strains was also carried out before incubation with dextranase, after $1 \mathrm{~h}$ incubation with dextranase, and after $24 \mathrm{~h}$ incubation with dextranase.

When glucan-positive strains were cultured serially in the laboratory they lost the capacity to produce dextran after 1618 passages. When glucan-positive strains were grown in a medium which lacks sucrose such as TSB, or the chemically defined synthetic medium (FMC) of Terleckcyj and collaborators (19), they were shown to be unable to synthesize glucan. Adherence studies to normal and abnormal valve leaflets were carried out with bacteria grown under these conditions to determine the role of endogenous glucan production in bacterial adherence.

\section{RESULTS}

Adherence of streptococcal strains to normal canine valve leaflets. Comparison of adherence ratios for the 18 streptococcal strains studied reveals important differences (Table II). The adherence ratios of S. mutans, 
TABLE II

Adherence of Streptococcal Strains to Canine Aortic, Mitral, and Tricuspid Valve Leaflets Calculated from Viable Counts*

\begin{tabular}{|c|c|c|c|c|}
\hline \multirow[b]{2}{*}{ Bacterial strain } & \multirow{2}{*}{$\begin{array}{c}\text { Number of } \\
\text { observations }\end{array}$} & \multicolumn{3}{|c|}{$\begin{array}{l}\text { Adherence ratio }\left(\times 10^{5}\right) \\
\text { calculated from viable counts }\end{array}$} \\
\hline & & Aortic & Mitral & Tricuspid \\
\hline & & \multicolumn{3}{|c|}{$m e a n \pm S E M$} \\
\hline S. mutans 6715 & 4 & $928 \pm 5$ & $1,086 \pm 2$ & $941 \pm 7$ \\
\hline S. mutans SS-909 & 3 & $952 \pm 23$ & $1,009 \pm 84$ & $902 \pm 17$ \\
\hline S. mutans SS-980 & 4 & $902 \pm 40$ & $840 \pm 84$ & $962 \pm 24$ \\
\hline S. mutans CR-1 & 4 & $1,001 \pm 30$ & $980 \pm 20$ & $996 \pm 40$ \\
\hline S. salivarius CM-6 & 4 & $352 \pm 8$ & $343 \pm 5$ & $355 \pm 1$ \\
\hline S. sanguis CR-100 & 3 & $900 \pm 20$ & $1,002 \pm 26$ & $878 \pm 36$ \\
\hline S. sanguis CR-101 & 3 & $1,012 \pm 21$ & $982 \pm 71$ & $974 \pm 42$ \\
\hline S. bovis CR-200 & 3 & $994 \pm 13$ & $976 \pm 38$ & $899 \pm 62$ \\
\hline S. bovis CR-1 & 4 & $952 \pm 10$ & $980 \pm 6$ & $923 \pm 18$ \\
\hline Enterococcus 26651 & 2 & $964 \pm 28$ & $897 \pm 27$ & $341 \pm 22$ \\
\hline Enterococcus KG-3 & 5 & $1,238 \pm 101$ & $908 \pm 140$ & $325 \pm 89$ \\
\hline S. faecalis 32426 & 2 & $1,015 \pm 15$ & $991 \pm 20$ & $101 \pm 15$ \\
\hline S. faecalis liquifaciens & 3 & $508 \pm 7$ & $496 \pm 26$ & $129 \pm 3$ \\
\hline S. faecalis zymogenes & 3 & $692 \pm 20$ & $413 \pm 20$ & $85 \pm 13$ \\
\hline S. durans & 3 & $613 \pm 150$ & $590 \pm 113$ & $110 \pm 12$ \\
\hline Group A streptococcus 25073 & 3 & $335 \pm 2$ & $271 \pm 4$ & $287 \pm 3$ \\
\hline Group B streptococcus 32114 & 2 & $251 \pm 8$ & $269 \pm 4$ & $290 \pm 2$ \\
\hline Group C Streptococcus 33378 & 2 & $411 \pm 3$ & $389 \pm 53$ & $343 \pm 22$ \\
\hline
\end{tabular}

* The bacterial suspensions in all experiments were standardized at $A_{590}=0.3$. Determinations of viable counts of all standardized suspensions were performed and varied from $3.8 \times 10^{8}$ to $4.6 \times 10^{8}$ colony forming $\mathrm{U} / \mathrm{ml}$.

I Adherence ratios presented were calculated from viable counts and are expressed as mean \pm SEM. Adherence ratios were also calculated from radioactivity in all experiments (data not shown). Results did not differ significantly from those obtained from viable counts.

S. sanguis, S. bovis, and bacteremic and(or) endocarditic strains of Group D streptococci were higher than for the other strains studied. Adherence ratios for a given strain when compared with different valves were similar, with the exception of Group D streptococci, whose adherence ratios were from 3 to 10 times lower with tricuspid valve leaflets than with mitral or aortic valve leaflets. These differences were seen regardless of the source of the bacterial strains and were significant $(P \leq 0.01)$ except for $S$. durans $(P>0.1)$. Adherence ratios calculated from isotopic labeling and viable counts were comparable $\left(r^{2}=0.96\right)$.

Adherence of streptococcal strains to normal human valve leaflets. Adherence ratios for each of seven streptococcal strains with normal human aortic, mitral, and tricuspid valve leaflets were comparable to the values obtained with leaflets from normal canine valves. As with canine valve leaflets, adherence ratios for Enterococcus KG-3 with normal human tricuspid valve leaflets were one-third of the values for aortic and mitral leaflets.

Adherence of streptococcal strains to canine interatrial septum. Adherence ratios for four streptococcal strains were determined for interatrial septum sections and were lower than the adherence ratios with aortic, mitral, or tricuspid valve leaflets. This difference was found to be highly significant $(P \leq 0.01)$. Adherence ratios with interatrial septum were from five to six times lower than the adherence ratios for valve leaflets with each of the streptococcal strains tested.

Relationship of adherence to concentration of bacteria in the incubation medium. For each bacterial strain tested the number of bacteria that became attached to aortic, mitral, or tricuspid valve sections was a constant proportion of the number of bacteria in the incubation medium. Representative data for a strain of S. mutans 6715 are presented in Fig. 1.

Adherence of streptococci to normal and damaged aortic valves. Seven of the eight streptococcal strains tested had similar adherence ratios with aortic valve leaflets (Table III). For all streptococcal strains tested adherence ratios with damaged aortic valves were higher than with normal aortic valves by factors of two to five. Adherence ratios for strains of streptococci associated with endocarditis in humans were four to five times higher for damaged aortic valve leaflets than for 


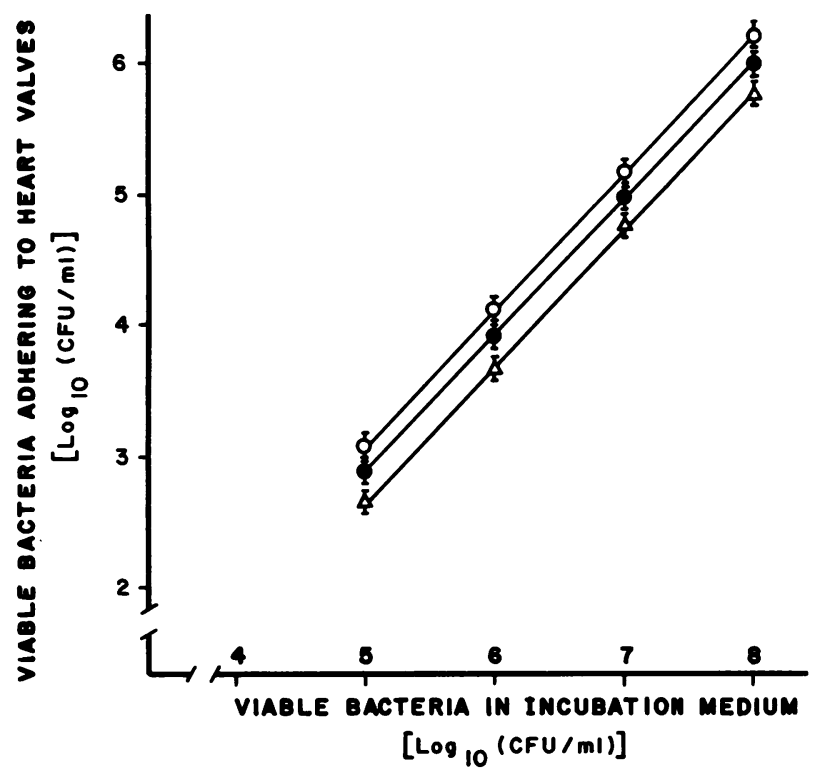

FIGURE 1 Relationship between concentration of bacteria in the incubation medium and adherence to heart valve sections. Data obtained for adherence of $S$. mutans 6715 to sections of different valve leaflets are represented by the following symbols: (O) aortic valve leaflets, $(\Delta)$ mitral valve leaflets, and (O) tricuspid valve leaflets. Each point is the mean of eight determinations, and the bars indicate standard error of the mean. Comparable data were obtained by measurement of radioactivity (data not shown). CFU, colony forming units.

normal aortic valve leaflets and for three of the four laboratory strains tested.

Effects of endogenous glucan synthesis, exogenous dextran, and dextranase on adherence. When the glucan-positive strain $S$. mutans 6715 was grown in TSB or FMC medium with or without added sucrose, the adherence ratios observed with damaged aortic valves were lower when sucrose was omitted from the medium and were similar to the adherence ratios observed with normal aortic valves with cells grown in medium either with or without sucrose (Table IV). When $S$. mutans strain 6715 was grown in a sucrosefree medium and dextran T-2000 was added to the bacterial suspension at $5 \mathrm{mg} / \mathrm{ml}$, the adherence ratios with normal valves were unchanged but the adherence ratios with damaged aortic valves increased to values similar to the adherence ratios when the strain was grown in a medium containing $5 \%$ sucrose $(P \geq 0.2)$.

Eight additional streptococcal strains, including both glucan-positive and glucan-negative strains, were grown in medium that contains or that lacks sucrose and then adherence ratios with normal and with damaged canine aortic valves were compared (Table V). With normal aortic valve leaflets, the adherence ratios for each strain were similar to those with cells grown in medium that contains or that lacks sucrose. Adherence of the glucan-positive streptococci, including S. mutans, S. sanguis, and S. bovis to damaged aortic valve sections was dependent on the conditions of cultivation of the bacteria. In each case adherence ratios with bacteria grown in the presence of sucrose were approximately five times higher than with bacteria grown in the absence of sucrose. In contrast, the adherence ratios of the glucan-negative strains Enterococcus KG-3 and S. salivarius CM-6 with

TABLE III

Adherence of Streptococcal Strains to Normal and Damaged Aortic Canine Valve Leaflets*

\begin{tabular}{|c|c|c|c|c|c|}
\hline \multirow[b]{3}{*}{ Bacterial strain } & \multirow[b]{3}{*}{$\begin{array}{c}\text { Number of } \\
\text { observations }\end{array}$} & \multicolumn{4}{|c|}{ Adherence ratio $\left(\times 10^{5}\right)$} \\
\hline & & \multicolumn{2}{|c|}{ Normal aortic } & \multicolumn{2}{|c|}{ Damaged aortic } \\
\hline & & $\begin{array}{c}\text { Calculated } \\
\text { from } \\
\text { viable } \\
\text { counts }\end{array}$ & $\begin{array}{c}\text { Calculated } \\
\text { from } \\
\text { isotopic } \\
\text { labeling }\end{array}$ & $\begin{array}{c}\text { Calculated } \\
\text { from } \\
\text { viable } \\
\text { counts }\end{array}$ & $\begin{array}{c}\text { Calculated } \\
\text { from } \\
\text { isotopic } \\
\text { labeling }\end{array}$ \\
\hline & & \multicolumn{4}{|c|}{ mean $\pm S E M$} \\
\hline S. mutans 6715 & 4 & $928 \pm 20$ & $895 \pm 16$ & $5,100 \pm 390$ & $4,728 \pm 301$ \\
\hline S. mutans SS-909 & 4 & $952 \pm 45$ & $1,008 \pm 36$ & $4,380 \pm 208$ & $5,019 \pm 184$ \\
\hline S. mutans SS-980 & 4 & $902 \pm 42$ & $901 \pm 29$ & $4,600 \pm 412$ & $4,500 \pm 200$ \\
\hline S. mutans CR-1f & 4 & $1,001 \pm 38$ & $916 \pm 29$ & $5,000 \pm 300$ & $4,543 \pm 336$ \\
\hline S. sanguis CR-100‡ & 4 & $920 \pm 20$ & $899 \pm 30$ & $3,956 \pm 402$ & $4,396 \pm 211$ \\
\hline S. bovis CR-200 & 4 & $990 \pm 15$ & $895 \pm 18$ & $4,732 \pm 130$ & $4,376 \pm 355$ \\
\hline Enterococcus KG-3\$ & 4 & $1,100 \pm 100$ & $1,095 \pm 216$ & $5,373 \pm 245$ & $5,332 \pm 265$ \\
\hline S. salivarius CM-6 & 4 & $356 \pm 18$ & $435 \pm 36$ & $776 \pm 44$ & $874 \pm 18$ \\
\hline
\end{tabular}

* The bacterial suspensions in all experiments were standardized at $A_{590}=0.3$. Determinations of viable counts of all standardized suspensions were performed and varied from $3.6 \times 10^{8}$ to $3.9 \times 10^{8}$ colony forming $\mathrm{U} / \mathrm{ml}$. All the experiments were performed utilizing TSB with $5 \%$ sucrose.

f Endocarditis strain. 
TABLE IV

Effects of Endogenous Glucan Synthesis and Exogenous Dextran on Adherence of Streptococcus Mutans 6715 to Normal and Damaged Aortic Canine Leaflets*

\begin{tabular}{|c|c|c|c|c|c|}
\hline \multirow[b]{3}{*}{ Growth condition $\downarrow$} & \multirow[b]{3}{*}{$\begin{array}{l}\text { Number of } \\
\text { observations }\end{array}$} & \multicolumn{4}{|c|}{ Adherence ratio $\left(\times 10^{5}\right)$} \\
\hline & & \multicolumn{2}{|c|}{ Normal aortic } & \multicolumn{2}{|c|}{ Damaged aortic } \\
\hline & & $\begin{array}{c}\text { Calculated } \\
\text { from } \\
\text { viable } \\
\text { counts }\end{array}$ & $\begin{array}{c}\text { Calculated } \\
\text { from } \\
\text { isotopic } \\
\text { labeling }\end{array}$ & $\begin{array}{c}\text { Calculated } \\
\text { from } \\
\text { viable } \\
\text { counts }\end{array}$ & $\begin{array}{c}\text { Calculated } \\
\text { from } \\
\text { isotopic } \\
\text { labeling }\end{array}$ \\
\hline & & \multicolumn{4}{|c|}{ mean $\pm S E M$} \\
\hline TSB + sucrose & 4 & $928 \pm 20$ & $895 \pm 16$ & $5,100 \pm 390$ & $4,728 \pm 301$ \\
\hline TSB - sucrose & 4 & $915 \pm 34$ & $878 \pm 24$ & $795 \pm 40$ & $824 \pm 40$ \\
\hline \multicolumn{6}{|l|}{ TSB - sucrose + dextran T-2000 } \\
\hline $5 \mathrm{mg} / \mathrm{ml}$ & 4 & $991 \pm 36$ & $894 \pm 20$ & $4,716 \pm 317$ & $4,929 \pm 300$ \\
\hline FMC + sucrose & 4 & $930 \pm 24$ & $901 \pm 23$ & $4,930 \pm 123$ & $4,898 \pm 190$ \\
\hline FMC & 4 & $900 \pm 28$ & $874 \pm 30$ & $789 \pm 38$ & $818 \pm 34$ \\
\hline $\mathrm{FMC}+$ dextran T-2000 $5 \mathrm{mg} / \mathrm{ml}$ & 4 & $974 \pm 29$ & $904 \pm 17$ & $4,984 \pm 190$ & $5,112 \pm 196$ \\
\hline
\end{tabular}

* The bacterial suspensions in all experiments were standardized at $A_{580}=0.3$. Determinations of viable counts of all standardized suspensions were performed and varied from $3.2 \times 10^{8}$ to $3.8 \times 10^{8}$ colony forming $\mathrm{U} / \mathrm{ml}$.

† FMC, chemically defined medium of Terleckyj et al. (19).

damaged aortic valve sections were not affected by the presence or absence of sucrose in the growth medium.

The effect of treatment of bacteria with dextranase on their subsequent adherence to damaged canine aortic valve leaflets was tested with five bacterial strains (Table VI). The adherence ratios of the glucan-positive strains $S$. mutans 6715 and S. mutans CR-1 decreased progressively as the concentration of dextranase was increased to $0.1 \mathrm{mg} / \mathrm{ml}$. Further increases in the concentration of dextranase did not result in any further decrease in the adherence ratios. The adherence ratios of the glucan-negative strains Enterococcus KG-3, Staphylococcus aureus and S. epidermidis were not affected by incubation with dextranase at concentrations up to the highest tested $(2 \mathrm{mg} / \mathrm{ml})$. When glucan-positive streptococcal strains were incubated for $1 \mathrm{~h}$ with dextranase $(0.2 \mathrm{mg} / \mathrm{ml})$, the morphology of the cells was unchanged and the extracellular polysaccharide production decreased by $10 \%$. Adherence ratios of glucan-positive streptococcal strains, incubated with dextranase for $\mathbf{l} \mathrm{h}$ to damaged aortic valves, were similar to adherence ratios found with normal valves. When dextranase was heated for $60 \mathrm{~min}$ at $60^{\circ} \mathrm{C}$, it lost its ability to depolymerize dextran and concomitantly lost its ability to modify glucan-positive bacteria in such a way that their adherence ratios with damaged aortic valve leaflets were decreased.

The effects of dextranase $(0.2 \mathrm{mg} / \mathrm{ml})$ treatment and of the addition of exogenous dextran T-2000 $(5 \mathrm{mg} / \mathrm{ml})$ on the adherence ratios of five glucan-positive strains and of one glucan-negative strain with damaged aortic valve leaflets were also tested after the strains were grown in
FMC medium with or without sucrose (Table VII). The addition of dextran to potentially glucan-positive strains either after growth in the absence of sucrose or after treatment with dextranase, restored the adherence ratios to levels found with the control bacteria grown in the presence of sucrose. The effect was seen with all glucan-positive strains regardless of the source, but was not seen with the glucan-negative strain Enterococcus KG-3.

\section{DISCUSSION}

In our original observation we found that gram-positive cocci adhered better than gram-negative bacilli to heart valves (1). With the new experimental data we have significantly extended our original work. The adherence ratios of most bacteremic and laboratory strains of streptococci to normal aortic, mitral, and tricuspid valve leaflets were similar. The adherence ratios of Group D streptococci were also from 3 to 10 times lower with tricuspid valve leaflets than with mitral leaflets. The explanation and implications for this phenomenon remain undefined but may be correlated with the lower reported involvement of enterococci in right-sided endocarditis $(24,25)$.

The initial event in the pathogenesis of bacterial endocarditis in man is the attachment of bacteria to heart valves. That the attachment of bacteria is most likely to occur to a damaged valve with a nonbacterial thrombotic endocarditis lesion was suggested by Angrist and Oka (26), and has been confirmed in the experimental rabbit model by Durack and Beeson (27). 
TABLE V

Adherence of Streptococci Grown under Dextran-Producing and Dextran Non-Producing Conditions to Normal and Damaged Canine Aortic Valve Leaflets*

\begin{tabular}{|c|c|c|c|c|c|c|}
\hline \multirow[b]{3}{*}{ Bacterial strain } & \multirow[b]{3}{*}{$\begin{array}{c}\text { Growth } \\
\text { medium }\end{array}$} & \multirow[b]{3}{*}{$\begin{array}{c}\text { Number } \\
\text { of } \\
\text { obser- } \\
\text { vations }\end{array}$} & \multicolumn{4}{|c|}{ Adherence ratios $\left(\times 10^{s}\right)$} \\
\hline & & & \multicolumn{2}{|c|}{ Normal aortic } & \multicolumn{2}{|c|}{ Damaged aortic } \\
\hline & & & $\begin{array}{c}\text { Calculated } \\
\text { from } \\
\text { viable } \\
\text { counts }\end{array}$ & $\begin{array}{c}\text { Calculated } \\
\text { from } \\
\text { isotopic } \\
\text { labeling }\end{array}$ & $\begin{array}{c}\text { Calculated } \\
\text { from } \\
\text { viable } \\
\text { counts }\end{array}$ & $\begin{array}{c}\text { Calculated } \\
\text { from } \\
\text { isotopic } \\
\text { labeling }\end{array}$ \\
\hline & & & \multicolumn{4}{|c|}{ mean $\pm S E M$} \\
\hline S. mutans 6715 & + & 4 & $928 \pm 20$ & $895 \pm 16$ & $5,100 \pm 390$ & $4,728 \pm 301$ \\
\hline S. mutans 6715 & - & 4 & $915 \pm 34$ & $878 \pm 24$ & $895 \pm 40$ & $824 \pm 40$ \\
\hline S. mutans SS-909 & + & 4 & $952 \pm 45$ & $1,008 \pm 36$ & $4,380 \pm 208$ & $5,019 \pm 184$ \\
\hline S. mutans SS-909 & - & 4 & $926 \pm 34$ & $958 \pm 39$ & $853 \pm 48$ & $931 \pm 70$ \\
\hline S. mutans SS-980 & + & 4 & $902 \pm 42$ & $901 \pm 39$ & $4,600 \pm 412$ & $4,500 \pm 200$ \\
\hline S. mutans SS-980 & - & 4 & $895 \pm 41$ & $949 \pm 35$ & $749 \pm 29$ & $891 \pm 29$ \\
\hline S. mutans CR-1 & + & 4 & $1,001 \pm 38$ & $916 \pm 29$ & $5,000 \pm 300$ & $4,543 \pm 336$ \\
\hline S. mutans CR-1 & - & 4 & $975 \pm 40$ & $903 \pm 41$ & $859 \pm 49$ & $803 \pm 76$ \\
\hline S. sanguis CR-100 & + & 4 & $920 \pm 20$ & $899 \pm 30$ & $3,956 \pm 402$ & $3,496 \pm 211$ \\
\hline S. sanguis CR-100 & - & 4 & $875 \pm 42$ & $900 \pm 29$ & $801 \pm 30$ & $916 \pm 41$ \\
\hline S. bovis CR-200 & + & 4 & $990 \pm 15$ & $895 \pm 18$ & $4,732 \pm 130$ & $4,376 \pm 355$ \\
\hline S. bovis CR-200 & - & 4 & $876 \pm 17$ & $785 \pm 84$ & $901 \pm 70$ & $819 \pm 64$ \\
\hline Enterococcus KG-3 & + & 4 & $1,100 \pm 100$ & $1,095 \pm 216$ & $5,373 \pm 245$ & $5,332 \pm 265$ \\
\hline Enterococcus KG-3 & - & 4 & $994 \pm 39$ & $894 \pm 99$ & $5,101 \pm 200$ & $5,216 \pm 300$ \\
\hline S. salivarius CM-6 & + & 4 & $356 \pm 18$ & $435 \pm 36$ & $776 \pm 44$ & $874 \pm 18$ \\
\hline S. salivarius CM-6 & - & 4 & $400 \pm 38$ & $462 \pm 33$ & $748 \pm 50$ & $749 \pm 38$ \\
\hline
\end{tabular}

* The bacterial suspensions in all experiments were standardized at $\mathbf{A}_{590}=\mathbf{0 . 3}$. Determinations of viable counts of all standardized suspensions were performed and varied from $3.1 \times 10^{8}$ to $3.6 \times 10^{8}$ colony forming $\mathrm{U} / \mathrm{ml}$. $\ddagger+$, TSB plus $5 \mathrm{mg}$ sucrose/ml, - , TSB without added sucrose.

The adherence of four endocarditis strains and three laboratory strains of $S$. mutans, a glucan-positive organism, was found to be five times higher to damaged valves than to normal valves. These results suggest the importance of adherence to platelet-fibrin thrombi. To confirm this hypothesis, valve sections with adherent bacteria were stained and examined by light micros- copy. When stained sections of damaged aortic valves were examined many adherent bacteria were seen in regions where endothelial damage was present, and few bacteria were seen on other surfaces of the valve sections. A representative photomicrograph is shown in Fig. 2.

The role of dextran in the adherence of dextran-posi-

TABLE VI

Effect of Treatment of Bacteria with Dextranase on Bacterial Adherence to Damaged Canine Aortic Valves*

\begin{tabular}{|c|c|c|c|c|c|c|c|}
\hline \multirow[b]{3}{*}{ Bacterial strain } & \multicolumn{7}{|c|}{ Adherence ratio $\left(\times 10^{5}\right)$} \\
\hline & \multicolumn{7}{|c|}{ Concentration of dextranase, $\mathrm{mg} / \mathrm{ml}$} \\
\hline & $\mathbf{0}$ & 0.025 & 0.05 & 0.1 & 0.2 & 0.4 & 2.0 \\
\hline & \multicolumn{7}{|c|}{ mean $\pm S E M$} \\
\hline Enterococcus KG-3\$ & $5,373 \pm 215$ & $5,250 \pm 300$ & $5,190 \pm 290$ & $5,370 \pm 239$ & $5,099 \pm 408$ & $5,190 \pm 219$ & $5,095 \pm 217$ \\
\hline S. mutans $6715 \S$ & $5,100 \pm 390$ & $3,820 \pm 300$ & $2,715 \pm 700$ & $615 \pm 70$ & $720 \pm 41$ & $617 \pm 40$ & $600 \pm 19$ \\
\hline S. mutans CR-1‡ & $5,000 \pm 300$ & $4,500 \pm 200$ & $4,000 \pm 400$ & $815 \pm 70$ & $619 \pm 41$ & $715 \pm 70$ & $690 \pm 25$ \\
\hline Staphylococcus aureus & $2,728 \pm 194$ & $2,826 \pm 219$ & - & - & $2,801 \pm 200$ & - & $2,898 \pm 196$ \\
\hline Staphylococcus epidermidis $\$$ & $2,310 \pm 209$ & $2,219 \pm 202$ & - & - & $2,320 \pm 302$ & - & $2,219 \pm 209$ \\
\hline
\end{tabular}

* The bacterial suspensions in all experiments were standardized at $A_{590}=0.3$. Determinations of viable counts of all standardized suspensions were performed and varied from $3.3 \times 10^{8}$ to $3.7 \times 10^{8}$ colony forming $\mathrm{U} / \mathrm{ml}$.

Endocarditis strain.

$\S$ Laboratory strain. 
TABLE VII

Effects of Dextran in Adherence of Glucan-Positive and Glucan-Negative Bacterial Strains to Damaged Canine Aortic Valves*

\begin{tabular}{|c|c|c|c|c|c|}
\hline \multirow[b]{3}{*}{ Bacterial strain } & \multicolumn{5}{|c|}{ Adherence ratio $\left(\times 10^{5}\right)$} \\
\hline & \multicolumn{5}{|c|}{ Growth condition } \\
\hline & $\begin{array}{l}\text { FMC } \\
+ \text { sucrose } \\
\text { control }\end{array}$ & $\begin{array}{c}\text { FMC } \\
+ \text { sucrose } \\
+ \text { dextranase } \\
0.2 \mathrm{mg} / \mathrm{ml}\end{array}$ & $\begin{array}{c}\text { FMC + sucrose } \\
+ \text { dextranase } 0.2 \mathrm{mg} / \mathrm{ml} \\
+ \text { dextran T-2000 } 5 \mathrm{mg} / \mathrm{ml}\end{array}$ & FMC & $\begin{array}{c}\text { FMC } \\
+ \text { dextran } \mathrm{T}-20005 \mathrm{mg} / \mathrm{ml}\end{array}$ \\
\hline & & & mean $\pm S E M$ & & \\
\hline S. mutans 6715 & $4,930 \pm 123$ & $720 \pm 17$ & $4,532 \pm 230$ & $789 \pm 38$ & $4,450 \pm 200$ \\
\hline S. mutans SS-909 & $4,802 \pm 204$ & $890 \pm 50$ & $4,900 \pm 200$ & $920 \pm 40$ & $4,809 \pm 200$ \\
\hline S. mutans SS-980 & $4,496 \pm 119$ & $850 \pm 26$ & $4,542 \pm 129$ & $868 \pm 47$ & $4,490 \pm 139$ \\
\hline S. mutans CR-1 & $4,543 \pm 336$ & $791 \pm 20$ & $4,117 \pm 219$ & $780 \pm 70$ & $4,320 \pm 301$ \\
\hline S. sanguis CR-100 & $5,000 \pm 204$ & $890 \pm 19$ & $4,880 \pm 136$ & $895 \pm 20$ & $4,911 \pm 118$ \\
\hline S. bovis CR-200 & $4,844 \pm 120$ & $869 \pm 40$ & $4,795 \pm 165$ & $892 \pm 26$ & $4,801 \pm 209$ \\
\hline Enterococcus KG-3 & $5,332 \pm 265$ & $5,290 \pm 326$ & $5,190 \pm 295$ & $5,300 \pm 300$ & $5,204 \pm 304$ \\
\hline
\end{tabular}

* The bacterial suspensions in all experiments were standardized at $A_{590}=0.3$. Determinations of viable counts of all standardized suspensions were performed and varied from $3.5 \times 10^{8}$ to $3.7 \times 10^{8}$ colony forming $\mathrm{U} / \mathrm{ml}$.

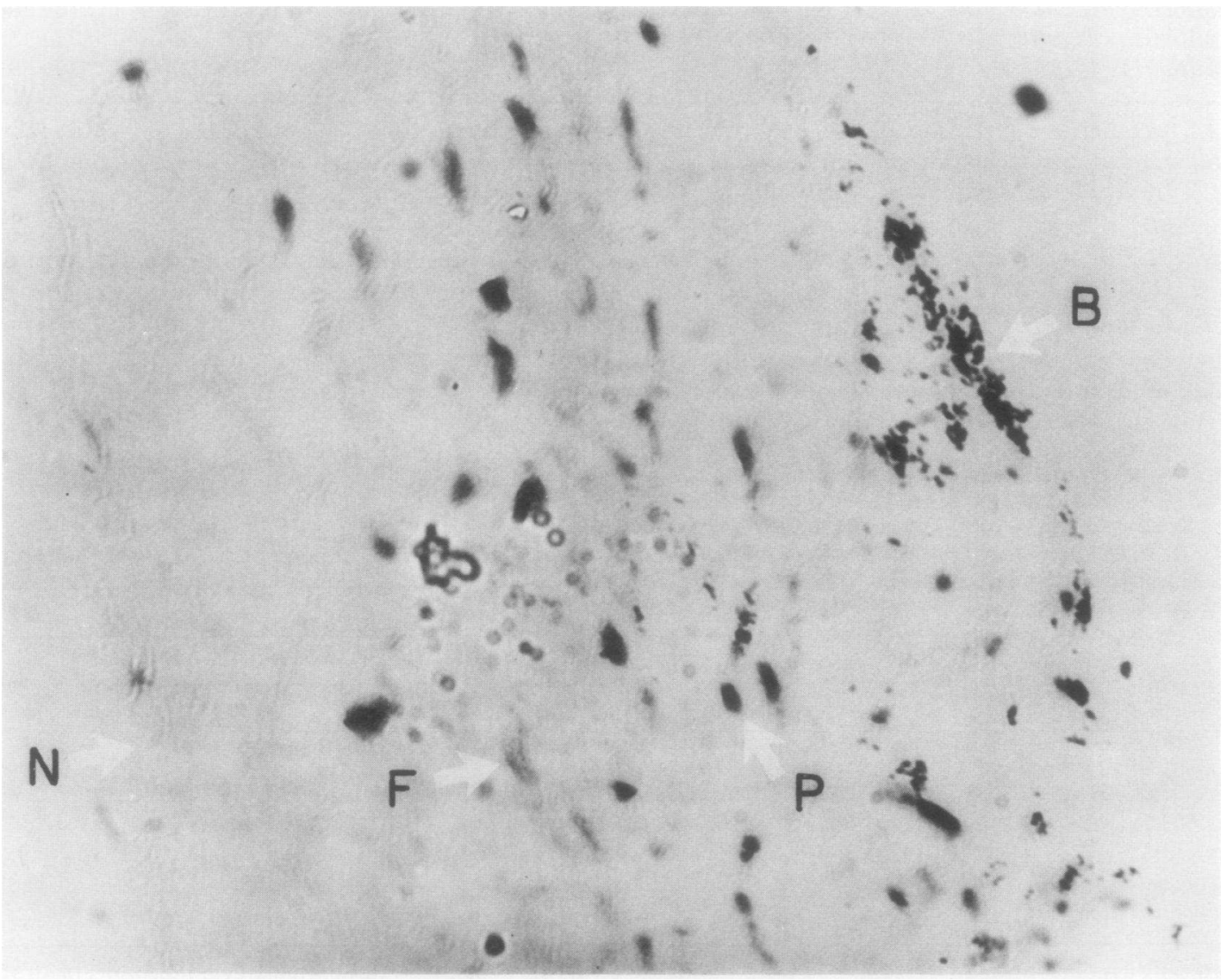

FIGURE 2 Representative photomicrograph $(\times 30)$ of a cross section of a damaged aortic valve leaflet, S. mutans 6715 adherent to the endothelial side covered with fibrin and platelets. $P$, platelets; F, fibrin; B, adherent bacteria; N, normal endothelium. 
tive streptococci to heart valves has been suggested previously (18). Our data demonstrates that the greater adherence of glucan-positive strains to damaged aortic valves over normal aortic valves depends on their ability to synthesize glucans. The precise role of glucans in the adherence of bacteria to damaged valves has not been defined at the biochemical level.

The effects of various concentrations of dextranase on the adherence of five bacterial strains showed that dextranase did not affect the adherence of glucan-negative strains, irrespective of the enzyme concentration. For glucan-positive strains the adherence progressively decreased as the enzyme concentration increased to $0.1 \mathrm{mg} / \mathrm{ml}$, but further increases in enzyme concentration did not affect adherence (Table VI). It is probable that the effect of dextranase is related to alterations in superficial chemical linkages in the extracellular dextran because the amount of extracellular dextran is just slightly reduced by incubation with dextranase for only $1 \mathrm{~h}$.

The source of dextran has been shown not to be important in the mediation of adherence, but the molecular weight of dextran plays a role because low molecular weight dextran does not mediate binding although dextran T-2000 is an effective agent (28). In our experiments the addition of exogenous dextran $\mathrm{T}-20005 \mathrm{mg} / \mathrm{ml}$ restores the adherence to levels found in controls. The addition of either dextran or sucrose to broth cultures or washed cell suspensions of $S$. mutans results in a rapid, dramatic cellular aggregation (29). Dextran-induced aggregation results from dextran cross linking of cells while sucrose-induced aggregation depends upon synthesis of dextran by dextransucrase and subsequent cellular binding of the product (30). Dextran binding by S. mutans may be mediated by two classes of cell associated proteins, dextransucrase, and a nonenzyme protein receptor $(17,31,32)$.

Whether in our system we are dealing with receptors for dextran in the platelet-fibrin thrombus and(or) the glucan-positive bacterial cell remains to be elucidated; further studies are needed to clarify the possible role of specific receptors.

Glucan-negative streptococcal strains like Enterococcus KG-3 also showed greater adherence to damaged aortic valve leaflets than to normal valve leaflets, but for these strains the enhanced adherence to damaged valve leaflets was not related either to endogenous glucan synthesis or to addition of dextran. This information points to factors other than glucan production that are important in the preferential adherence of glucannegative strains to damaged valves. This factor or factors remain undefined and merit further investigation.

The data presented help to clarify the role of dextran in the adherence of glucan-positive strains to damaged canine heart valves (covered with platelet and fibrin) and may be relevant for the pathogenesis of bacterial endocarditis. Gram-positive bacterial strains adhere better than gram-negative bacilli to all heart valves, but this adherence is increased if the valvular endothelium is damaged and covered with a platelet-fibrin thrombus. For glucan-positive strains of streptococci adherence to this platelet-fibrin thrombus is in part dependent upon the presence of high molecular weight glucans from any source.

In summary, the adherence of all bacterial strains to damaged aortic valves was significantly higher than to normal valves. The platelet-fibrin thrombus appears to represent a preferential site for bacterial adherence. The adherence of glucan-positive strains to damaged aortic valve sections was dependent on the presence of unmodified high molecular weight dextran and dextranase decreased adherence to control levels for these strains.

These data suggest that the high prevalence of glucan-positive strains among streptococci isolated from cases of endocarditis could be a reflection of the important role of glucans in bacterial adherence to damaged heart valves which is presumed to be the initial step in the pathogenesis of endocarditis. However, other factors such as the ability of the bacteria to multiply in vivo and to survive in the presence of normal host defenses must also be important in the development of endocarditis in man.

Addendum. After the manuscript was first submitted an article appeared with similiar findings (33).

\section{ACKNOWLEDGMENTS}

I want to thank Ms. Minerva Carrasco for technical assistance, Dr. Morton S. Swartz for suggesting the study of adherence to interatrial septum, and Dr. Randall K. Holmes for reviewing the manuscript.

This work was supported by the Veterans Administration and in part by the Puerto Rico Heart Association.

\section{REFERENCES}

1. Gould, K., C. H. Ramirez-Ronda, R. K. Holmes, and J. P. Sanford. 1975. Adherence of bacteria to heart values in vitro. J. Clin. Invest. 56: 1364-1370.

2. Ellen, R. P., and R. J. Gibbons. 1974. Parameters affecting the adherence and tissue tropisms of Streptococcus pyogenes. Infect. Immun. 9: 85-91.

3. van Houte, J., R. J. Gibbons, and A. J. Pulkkinen. 1971. Adherence as an ecological determinant for streptococci in the human mouth. Arch. Oral Biol. 16: 1131-1141.

4. Gibbons, R. J., and J. van Houte. 1971. Selective bacterial adherence to oral epithelial surfaces and its role as an ecological determinant. Infect. Immun. 3: 567-573.

5. Freter, R., and G. W. Jones. 1976. Adhesive properties of Vibrio cholerae: Nature of the interaction with intact mucosal surfaces. Infect. Immun. 14: 246-256.

6. Punsalang, A. P., Jr., and W. D. Sawyer. 1973. Role of pili in the virulence of Neisseria gonorrhoeae. Infect. Immun. 8: 255-263.

7. Powell, D. A., P. C. Hu, M. Wilson, A. M. Collier, and 
J. B. Baseman. 1976. Attachment of Mycoplasma pneumoniae to respiratory epithelium. Infect. Immun. 13: 959-966.

8. Mardh, P. A., and L. Weström. 1976. Adherence of bacteria to vaginal epithelial cells. Infect. Immun. 13: 661-666.

9. Gibbons, R. J., D. M. Spinell, and Z. Skobe. 1976. Selective adherence as a determinant of the host tropisms of certain indigenous and pathogenic bacteria. Infect. Immun. 13: 238-246.

10. Weinstein, L., and R. H. Rubin. 1973. Infective endocarditis. 1973. Prog. Cardiovasc. Dis. 16: 239-274.

11. van Houte, J., H. V. Jordan, and S. Bellack. 1971. Proportions of Streptococcus sanguis, an organism associated with subacute bacterial endocarditis, in human feces and dental plaque. Infect. Immun. 4: 658-659.

12. Neefe, L. I., J. H. Chretien, E. C. Delaha, and V. F. Garagusi. 1974. Streptococcus mutans endocarditis. JAMA (J. Am. Med. Assoc.). 230: 1298-1299.

13. Parker, M. T., and L. C. Ball. 1976. Streptococci and aerococci associated with systemic infection in man. $J$. Med. Microbiol. 9: 275-302.

14. Porterfield, J. S. 1950. Classification of the streptococci of subacute bacterial endocarditis. J. Gen. Microbiol. 4: $92-101$.

15. Hehre, E. J., and J. M. Neill. 1946. Formation of serologically reactive dextrans by streptococci from subacute bacterial endocarditis. J. Exp. Med. 83: 147-162.

16. Gibbons, R. J., and S. B. Banghart. 1967. Synthesis of extracellular dextran by cariogenic bacteria and its presence in human dental plaque. Arch. Oral Biol. 12: $11-24$.

17. Mukasa H. and H. D. Slade. 1973. Mechanism of adherence of Streptococcus mutans to smooth surfaces. I. Roles of insoluble dextran-levan synthetase enzymes and cell wall polysaccharide antigen in plaque formation. Infect. Immun. 8: 555-562.

18. Elliot, S. D. 1973. The incidence of Group H streptococci in blood cultures from patients with subacute bacterial endocarditis (SBE). J. Med. Microbiol. 6: XIV.

19. Terleckyj, B., N. P. Willett, and G. D. Shockman. 1975. Growth of several cariogenic strains of oral streptococci in a chemically defined medium. Infect. Immun. 11: 649-655.

20. Bernstein, L., and W. Weatherall. 1952. Statistics for Medical and other Biological Students. E. \& S. Livingstone Ltd., Edinburgh. 74-88

21. Murayama, Y., H. Wada, H. Hayashi, T. Uchida, I.
Yokomizo, and S. Hamada. 1973. Effects of dextranase from Spicaria violaceae (IFO 6120) on the polysaccharides produced by oral streptococci and on human dental plaque. J. Dent. Res. 52: 658-667.

22. Facklam, R. R. 1974. Characteristics of Streptococcus mutans isolated from human dental plaque and blood. Int. J. Syst. Bacteriol. 24: 313-319.

23. Hamada, S., J. Mizuno, Y. Murayama, T. Ooshima, N. Masuda, and S. Sobue. 1975. Effect of dextranase on the extracellular polysaccharide synthesis of Streptococcus mutans: Chemical and scanning electron microscopy studies. Infect. Immun. 12: 1415-1425.

24. Cherubin, C. E., and H. C. Neu. 1971. Infective endocarditis at the Presbyterian Hospital in New York City from 1938-1967. Am. J. Med. 51: 83-96.

25. Roberts, W. C., and N. A. Buchbinder. 1972. Right-sided valvular infective endocarditis. A clinicopathologic study of twelve necropsy patients. Am. J. Med. 53: 7-19.

26. Angrist, A. A., and M. Oka. 1963. Pathogenesis of bacterial endocarditis. JAMA (J. Am. Med. Assoc.). 183: 249-252.

27. Durack, D. T., and P. B. Beeson. 1972. Experimental bacterial endocarditis. I. Colonization of sterile vegetation. Br. J. Exp. Pathol. 53: 44-49.

28. Bourgeau, G., and B. C. McBride. 1976. Dextran-mediated interbacterial aggregation between dextran-synthesizing streptococci and Actinomyces viscosus. Infect. Immun. 13: $1228-1234$.

29. Gibbons, R. J., and R. J. Fitzgerald. 1969. Dextran-induced agglutination of Streptococcus mutans, and its potential role in the formation of microbial dental plaques. J. Bacteriol. 98: 341-346.

30. Guggenheim, B., and H. E. Schroeder. 1967. Biochemical and morphological aspects of extracellular polysaccharides produced by cariogenic streptococci. Helv. Odontol. Acta. 11: 131-152.

31. Kelstrup, J., and T. D. Funder-Nielsen. 1974. Adhesion of dextran to Streptococcus mutans. J. Gen. Microbiol. 81: 485-489.

32. Mukasa, H., and H. D. Slade. 1974. Mechanism of adherence of Streptococcus mutans to smooth surfaces. II. Nature of the binding site and absorption of the dextranlevan synthetase enzymes on the cell-wall surface of the streptococcus. Infect. Immun. 9: 419-429.

33. Scheld, W. M., J. A. Valone, and M. A. Sande. 1978. Bacterial adherence in the pathogenesis of endocarditis. Interaction of bacterial dextran, platelets, and fibrin. $J$. Clin. Invest. 61: 1394-1404. 